\title{
Effect of different pre-calving feeding strategies on the metabolic status and lactation performance of dairy cows
}

\author{
R. Mikuła ${ }^{1,3}$, E. Pruszyńska-Oszmałek ${ }^{2}$, P. Maćkowiak² and W. Nowak ${ }^{1}$ \\ Poznań University of Life Sciences \\ 1 Department of Animal Nutrition, Wołyńska 33, 60-637 Poznań, Poland \\ ${ }^{2}$ Department of Animal Physiology and Biochemistry, Wołyńska 35, 60-637 Poznań, Poland
}

KEY WORDS: close-up, metabolic disorders, blood indices, fertility parameters, milk yield, dairy cows

Received: $\quad 16$ March 2018

Revised: $\quad 27$ June 2018

Accepted: 13 November 2018

${ }^{3}$ Corresponding author:

e-mail: robert.mikula@up.poznan.pl

\begin{abstract}
The objective of the study was to investigate the metabolic, health and production consequences of selected pre-calving feeding strategies. Forty Polish Holstein-Friesian multiparous dairy cows were dried off at day 56 before parturition and assigned to 2 pre-calving treatments: CON - a 5-week far-off period and a 3-week close-up period, and SHORT - a 7-week far-off period and a 1-week close-up period with a fresh transition diet. Shortening the close-up period had no effect on body condition score during the dry period; however, a tendency to the lowest body condition score (BCS) losses were observed in the SHORT group during the first 56 days of lactation $(P=0.13)$. Cows from the SHORT group tended to have higher glucose concentration 3 days before calving $(P=0.13)$. Shortening the close-up period resulted in a higher insulin level $(P=0.04)$ and lower concentration of $\beta$-hydroxybutyric acid in the blood 28 days after parturition $(P=0.03)$. Cows from the SHORT group were characterized by a higher concentration of triiodothyronine 3 days before calving $(P=0.03)$ and tended to have a higher level of thyroxine 5 days after parturition $(P=0.09)$. A tendency to higher yield of energy corrected milk $(P=0.09)$ and fat content in milk was observed in the SHORT group $(P=0.11)$. There were no differences between treatments in terms of reproductive performance. Simplification of the transition period management and shortening of the close-up period led to a positive tendency to increase the yield of energy corrected milk, with no negative effect on the metabolic status and reproductive performance of dairy cows.
\end{abstract}

\section{Introduction}

In recent years, high yielding dairy cow nutritionists have focused on dry and transition periods, because feeding and management strategies in these periods could affect cows' health as well as reproductive and yield performance in consecutive lactation (Sordillo and Mavangira, 2014; Roche et al., 2015). A decrease in dry matter intake around the time of calving may lead to a negative energy balance in early lactation, which is probably the main problem of cost-effective milk production. In such a situation mobilization of fatty acids from the adipose tissue increases non-esterified fatty acids (NEFA) concentration in blood. Rising level of NEFA in dairy cows' blood during negative energy balance is often associated with the accumulation of triglycerides in hepatocytes and impairment of liver function resulting in an elevated ketone production. Moreover, increased blood NEFA levels could have a negative effect on oocyte development and reproductive performance 
(Walsh et al., 2007). Sordillo and Raphael (2013) claimed that a progressive increase in the blood NEFA level before calving may be considered a significant factor affecting inflammatory responses of transition cows. Higher blood NEFA concentrations could be related to an increased risk of displaced abomasum (Chapinal et al., 2011), metritis and retained placenta (Ospina et al., 2010a), mastitis (Suriyasathaporn et al., 2000) and lower milk yield (Ospina et al., 2010b), while it may also result in early-lactation culling risk (Roberts et al., 2012). Thus, many authors have investigated potential methods to reduce blood NEFA concentration using feed additives (Adamski et al., 2011; Piantoni and Allen, 2015). In the present literature many dry cow feeding strategies have also been presented. Some authors attempted e.g., to decrease energy density in dry period diets (Dann et al., 2006; Janovick and Drackley, 2010, Nowak et al., 2013). Moreover, the results described by Zhang et al. (2015) proved a positive effect on metabolism and production during early lactation in cows fed a low energy density diet during the close-up period. Limiting energy intake before parturition may result in an improved energy status in early lactation and lead to a lower mobilization of fatty acids from the adipose tissue and decrease in the risk of metabolic disorders postpartum.

We hypothesized that simplification of the transition period management in dairy cows and shortening the close-up period to one week as well as implementation of a low energy far-off diet one week before parturition, followed by a high energy fresh transition diet with no close-up diet will reduce the negative energy balance postpartum and could have a positive effect on the metabolism of lactating cows as well as improve their fertility and milk performance.

The aim of the present study was to investigate the metabolic and production consequences of shortening the close-up period to one week before calving, preceded by a fresh transition diet.

\section{Material and methods}

All animal procedures were conducted in accordance with the guidelines of the Polish Council for Animal Care. The protocol for this study was approved by the Local Animal Care Committee No. 10 of the Poznan University of Life Sciences (Poland).

\section{Animal management, experimental design and diets}

Forty Polish Holstein-Friesian multiparous highyielding dairy cows with body weight of $650 \mathrm{~kg}$ at
Table 1. Treatments scheme

\begin{tabular}{|c|c|c|c|c|c|c|c|c|c|c|c|}
\hline \multirow{2}{*}{ Group } & \multicolumn{8}{|c|}{ Prepartum, week } & \multicolumn{3}{|c|}{ Postpartum, week } \\
\hline & -8 & -7 & -6 & -5 & -4 & -3 & -2 & -1 & +1 & +2 & +3 \\
\hline CON & \multicolumn{5}{|c|}{ Far-off diet } & Close & -up d & & \multicolumn{3}{|c|}{ Fresh transition diet } \\
\hline SHORT & \multicolumn{7}{|c|}{ Far-off diet } & & \multicolumn{3}{|c|}{ Fresh transition diet } \\
\hline
\end{tabular}

dry-off period were included in the experiment. On the basis of their body weight, body condition score (BCS; Edmonson et al., 1989) at dry-off, previous lactation milk yield and lactation number, the cows 56 days before the expected time of parturition were randomly assigned to 1 of the 2 pre-calving treatments. The experimental treatments were: $\mathrm{CON}-$ a 5-week far-off period and a 3-week close-up period, and SHORT - a 7-week far-off period and a 1-week close-up period with a fresh transition diet (Table 1).

The study started 56 days before parturition and covered the far-off and close-up periods as well as the first 56 days of lactation. The nutritional values of the feed components were calculated on the basis of the analysed nutrient contents using the PrevAlim 3.23 software (Educagri/INRA, Theix, France). The diets were balanced according to the French INRA system recommendations (INRAtion 3.3 software, Educagri/ INRA, Theix, France). Cows were fed a total mixed ration (TMR), which was served to the animals twice a day at 9:00 and 14:30. The diets were based on a silage made of maize, grass, alfalfa as well as concentrates (soybean meal, rapeseed meal, barley grain, triticale grain) with mineral and vitamin supplements. The animals were fed a far-off diet [ $(0.69$ feed unit for lactation (UFL)/kg dry matter (DM), $66 \mathrm{~g}$ protein digested in the small intestine (PDI) $/ \mathrm{kg} \mathrm{DM}, 53.4 \%$ neutral detergent fibre (NDF)], close-up diet (0.85 UFL/ $\mathrm{kg}$ DM, $99 \mathrm{~g}$ PDI $/ \mathrm{kg}$ DM, 33.2\% NDF) and fresh transition diet (0.92 UFL/kg DM, $108 \mathrm{~g}$ PDI/kg DM, $29.3 \% \mathrm{NDF}$ ) according to the treatment scheme (Tables 1 and 2).

During the experiment, the cows were housed in groups. Individual DM intake was unavailable. Instead, voluntary DM intake was measured daily for the whole group during the far-off and close-up periods.

\section{Sample collection and analytical method}

Weekly composite forage, concentrate and TMR samples were collected for monthly analyses using wet chemistry for crude protein (CP, method 976.05; AOAC International, 2005), neutral detergent fibre (NDF, PN-EN ISO 16472:2007), acid detergent fibre (ADF, PN-EN ISO 13906:2009), calcium 
Table 2. Ingredient and nutrient composition of the experimental total mixed ration (TMR) diets

\begin{tabular}{|c|c|c|c|}
\hline Indices & Far-off diet & $\begin{array}{l}\text { Close-up } \\
\text { diet }\end{array}$ & $\begin{array}{l}\text { Fresh } \\
\text { transition diet }\end{array}$ \\
\hline \multicolumn{4}{|l|}{ Ingredients, $\%$ of DM } \\
\hline wheat straw & 36.6 & & 3.3 \\
\hline soybean meal & 6.0 & 6.0 & 6.3 \\
\hline alfalfa silage & 8.1 & 11.1 & 11.0 \\
\hline maize silage & 25.7 & 25.8 & 20.8 \\
\hline grass silage & 21.1 & & \\
\hline maize grain silage & & 9.4 & 9.6 \\
\hline sugar beet pulp silage & & 6.0 & 6.5 \\
\hline brewer's grain silage & & 9.0 & 10.2 \\
\hline hay & & 7.7 & \\
\hline barley grain & & 5.2 & 3.2 \\
\hline triticale grain & & 6.0 & 15.1 \\
\hline rapeseed meal & & 7.1 & 7.2 \\
\hline glycerol & & 1.9 & 1.1 \\
\hline fat & & & 2.2 \\
\hline minerals and vitamins & 2.5 & 4.8 & 3.5 \\
\hline \multicolumn{4}{|c|}{ Nutrient concentration, in $\mathrm{kg} D \mathrm{DM}$} \\
\hline UFL & 0.69 & 0.85 & 0.92 \\
\hline PDIN, g & 66 & 101 & 110 \\
\hline PDIE, g & 69 & 99 & 108 \\
\hline $\mathrm{CP}, \%$ & 11.3 & 14.7 & 16.8 \\
\hline NDF, $\%$ & 53.4 & 33.2 & 29.3 \\
\hline$A D F, \%$ & 35.2 & 21.3 & 19.0 \\
\hline $\mathrm{Ca}, \mathrm{g}$ & 5.7 & 8.6 & 10.2 \\
\hline $\mathrm{P}, \mathrm{g}$ & 3.0 & 3.4 & 4.1 \\
\hline
\end{tabular}

DM - dry matter; UFL - feed unit for lactation (1700 kcal NE $)$; PDIN - dietary protein undegraded in the rumen, but truly digestible in the small intestine and microbial protein which could be synthesized in the rumen from degraded dietary nitrogen, when energy and other nutrients are not limiting; PDIE - dietary protein undegraded in the rumen, but truly digestible in the small intestine and microbial protein which could be synthesized in the rumen from the energy available in the rumen, when degraded nitrogen and other nutrients are not limiting; CP - crude protein; NDF - natural detergent fibre; ADF - acid detergent fibre

(Ca, method 968.08; AOAC International, 2005) and phosphorus (P, PN ISO 6491:2000). Body condition scoring (BCS) was performed during the far-off period (days -56 and -21 ), on the parturition day and on days 14 and 56 of lactation.

Blood was sampled from the jugular vein $3 \mathrm{~h}$ after morning feeding on days $-30,-3$ of the prepartum and on days 5 and 28 during lactation. Blood samples were collected into tubes with polystyrene separating granules covered with a clot activator and then the aliquots were rotated in a centrifuge. Next, serum was frozen and stored $\left(-20{ }^{\circ} \mathrm{C}\right)$ for further analyses. The concentrations of glucose and $\beta$-hydroxybutyric acid (BHBA) were analysed colourimetrically using the endpoint method. The activity of aspartate aminotransferase (AST) was analysed by colourimetry applying the kinetic method. Absorbance of the incubated samples was measured using a Marcel Media spectrophotometer (Marcel S.A., Zielonka, Poland) and a Hellma microcuvette (Hellma GmbH \& Co., Müllheim, Germany). The concentrations of non-esterified fatty acids (NEFA) were analysed according to the Duncombe colorimetric method (Duncombe, 1964). Serum concentrations of insulin, insulin-like growth factor I (IGF-I), triiodothyronine (T3) and thyroxine (T4) were analysed by means of radioimmunoassay (RIA). Kits of reagents used for blood serum analyses are shown in Table 3.

Table 3. Kits of reagents used for the analysis of blood serum indices

\begin{tabular}{|c|c|c|}
\hline Biochemical indices & Test & Producer \\
\hline Glucose & G 7518-400 & \multirow{3}{*}{$\begin{array}{l}\text { Pointe Scientific (Canton, } \\
\text { OH, USA) }\end{array}$} \\
\hline$\beta$-hydroxybutyric acid & $\mathrm{H} 7587-58$ & \\
\hline $\begin{array}{l}\text { Aspartate } \\
\text { aminotransferase }\end{array}$ & A7561-450 & \\
\hline Insulin & $\mathrm{Pl}-12 \mathrm{~K}$ & $\begin{array}{l}\text { Millipore Corporation } \\
\text { (Burlington, VT, USA) }\end{array}$ \\
\hline Thyroxine & OCPG 07-F4 & CISBIO International \\
\hline Triiodothyronine & ОСРЕ07-Т3 & (Codolet, France) \\
\hline Insulin-like growth factor I & DSL-2800 & $\begin{array}{l}\text { Diagnostic Systems Lab. } \\
\text { (Webster, NY, USA) }\end{array}$ \\
\hline
\end{tabular}

The cows were milked twice a day and individual milk yields were recorded daily during 56 days of lactation. Milk from morning and afternoon milkings was sampled at weekly intervals. Samples were collected into tubes with 2-bromo-2-nitropropane-1,3-diol. Next, samples were refrigerated and delivered to a commercial laboratory (Milk Quality Laboratory, the Polish Federation of Cattle Breeders and Dairy Farmers, Krotoszyn, Poland) for analyses of fat, protein, lactose and urea concentrations as well as somatic cell counts.

Energy corrected milk (ECM) was calculated according to Reist et al. (2003) as:

$$
\begin{gathered}
{[(0.038 \times \mathrm{g} \text { crude fat }+0.024 \times \mathrm{g} \text { crude protein }+} \\
+0.017 \times \mathrm{g} \text { lactose }) \times \mathrm{kg} \text { milk }] / 3.14
\end{gathered}
$$

\section{Reproductive performance and health monitoring}

Reproductive performance parameters (days to first ovulation, first-service conception rate, services per conception and day open) were also recorded. The first ovulation was identified with an ultrasound scanner equipped with a $7.5 \mathrm{MHz}$ convex transducer (Pie Medical Scanner 200; Pie Medical Imaging BV, Maastricht, The Netherlands). During the study cows' health was monitored and recorded daily. 


\section{Statistical analysis}

Results were processed statistically using Student's t-test with the PROC TTEST procedure of the SAS 9.1 (2004) SAS ${ }^{\circledR} /$ STAT software package (SAS Institute Inc., Cary, NC, USA). The PROC MEANS and PROC UNIVARIATE procedures were also applied. To interpret the results, the following criteria of significance were used: significance $(P \leq 0.05)$, tendency to significance $(P \leq 0.1)$ and non-significant $(P>0.1)$.

\section{Results}

Shortening the close-up period influenced neither the body condition score (BCS) nor condition changes during the dry period $(P>0.05)$. A tendency to lowest BCS losses (0.16 BCS point) was observed in cows assigned to the SHORT group during the first 56 days of lactation $(P=0.13$; Table 4$)$.

Average DM intake in the far-off (12.9 vs $12.7 \mathrm{~kg}$ ) and close-up periods (12.5 vs $12.6 \mathrm{~kg}$ ) was similar between the groups.

Table 4. The effect of shortening close-up period on body condition score (BCS)

\begin{tabular}{|c|c|c|c|c|c|}
\hline \multirow{2}{*}{ Group } & \multicolumn{5}{|c|}{ Days from calving } \\
\hline & -56 & -21 & 0 & +14 & +56 \\
\hline$\overline{\mathrm{CON}}$ & 3.65 & 3.64 & 3.54 & 3.37 & 3.25 \\
\hline SHORT & 3.65 & 3.57 & 3.50 & 3.38 & 3.37 \\
\hline SEM & 0.04 & 0.03 & 0.03 & 0.04 & 0.04 \\
\hline$P$-value & 0.99 & 0.35 & 0.59 & 0.90 & 0.16 \\
\hline \multirow{2}{*}{ Group } & \multicolumn{5}{|c|}{ BCS changes } \\
\hline & $-56 \rightarrow-21$ & $-21 \rightarrow 0$ & $-56 \rightarrow 0$ & $0 \rightarrow 14$ & $0 \rightarrow 56$ \\
\hline$\overline{\mathrm{CON}}$ & -0.01 & -0.10 & -0.11 & -0.17 & -0.29 \\
\hline SHORT & -0.08 & -0.07 & -0.15 & -0.12 & -0.13 \\
\hline SEM & 0.02 & 0.04 & 0.04 & 0.04 & 0.04 \\
\hline$P$-value & 0.17 & 0.74 & 0.68 & 0.82 & 0.13 \\
\hline
\end{tabular}

Groups: CON - 5-week far-off period and 3-week close-up period, SHORT - 7-week far-off period and 1-week close-up period; SEM - standard error of mean

Cows from the SHORT group tended to have higher blood glucose concentrations at $1.50 \mathrm{mmol} / 1$ vs $1.02 \mathrm{mmol} / \mathrm{l}$ on day 3 before calving $(P=0.13$; Table 5). Shortening the close-up period resulted in higher blood insulin levels on day 28 after parturition $(P=0.04)$. Lower concentrations of $\beta$-hydroxybutyric acid $(0.752 \quad \mathrm{mmol} / \mathrm{l}$ vs $0.977 \mathrm{mmol} / \mathrm{l}$ ) were recorded in blood from cows assigned to the SHORT group at day 28 after calving $(P=0.03)$. Cows from the SHORT group were characterized by higher concentrations of $\mathrm{T} 3$ on
Table 5. The effect of shortening close-up period on serum hormones and metabolites

\begin{tabular}{|c|c|c|c|c|c|}
\hline \multirow{3}{*}{ Indices } & \multirow{3}{*}{ Group } & \multicolumn{4}{|c|}{ Time of blood sample collection } \\
\hline & & \multicolumn{2}{|c|}{ prepartum } & \multicolumn{2}{|c|}{ postpartum } \\
\hline & & -30 day & -3 day & 5 day & 28 day \\
\hline \multirow{4}{*}{$\begin{array}{l}\text { Glucose, } \\
\mathrm{mmol} / \mathrm{l}\end{array}$} & CON & 2.52 & 1.02 & 1.10 & 1.62 \\
\hline & SHORT & 2.99 & 1.50 & 1.23 & 1.46 \\
\hline & SEM & 0.17 & 0.16 & 0.16 & 0.16 \\
\hline & $P$-value & 0.21 & 0.13 & 0.68 & 0.64 \\
\hline \multirow{4}{*}{$\begin{array}{l}\text { Insulin, } \\
\mu U / m l\end{array}$} & CON & 14.4 & 23.2 & 9.19 & 7.50 \\
\hline & SHORT & 18.4 & 18.2 & 8.66 & 10.2 \\
\hline & SEM & 1.23 & 2.24 & 0.88 & 0.06 \\
\hline & $P$-value & 0.09 & 0.29 & 0.77 & 0.04 \\
\hline \multirow{4}{*}{$\begin{array}{l}\text { IGF-I, } \\
\mathrm{ng} / \mathrm{ml}\end{array}$} & CON & 334 & 351 & 215 & 274 \\
\hline & SHORT & 339 & 343 & 218 & 251 \\
\hline & SEM & 11.9 & 11.3 & 14.4 & 17.4 \\
\hline & $P$-value & 0.82 & 0.72 & 0.91 & 0.50 \\
\hline \multirow{4}{*}{$\begin{array}{l}\mathrm{NEFA}, \\
\mathrm{mmol} / \mathrm{l}\end{array}$} & CON & 0.166 & 0.244 & 0.634 & 0.391 \\
\hline & SHORT & 0.189 & 0.283 & 0.718 & 0.406 \\
\hline & SEM & 0.02 & 0.03 & 0.06 & 0.06 \\
\hline & $P$-value & 0.61 & 0.49 & 0.28 & 0.90 \\
\hline \multirow{4}{*}{$\begin{array}{l}\mathrm{BHBA}, \\
\mathrm{mmol} / \mathrm{l}\end{array}$} & CON & 0.658 & 0.657 & 0.842 & 0.977 \\
\hline & SHORT & 0.649 & 0.719 & 0.849 & 0.752 \\
\hline & SEM & 0.02 & 0.03 & 0.06 & 0.05 \\
\hline & $P$-value & 0.84 & 0.29 & 0.96 & 0.03 \\
\hline \multirow[t]{4}{*}{ AST, U/I } & CON & 75.3 & 36.7 & 82.3 & 58.8 \\
\hline & SHORT & 75.4 & 35.9 & 55.8 & 105 \\
\hline & SEM & 3.8 & 3.34 & 7.16 & 13.1 \\
\hline & $P$-value & 0.99 & 0.91 & 0.06 & 0.07 \\
\hline \multirow{4}{*}{$\begin{array}{l}\text { T3, } \\
\mathrm{ng} / \mathrm{ml}\end{array}$} & CON & 1.16 & 1.22 & 0.879 & 1.06 \\
\hline & SHORT & 1.27 & 1.38 & 0.820 & 1.18 \\
\hline & SEM & 0.04 & 0.04 & 0.06 & 0.05 \\
\hline & $P$-value & 0.15 & 0.03 & 0.62 & 0.28 \\
\hline \multirow{4}{*}{$\begin{array}{l}\mathrm{T} 4, \\
\mathrm{ng} / \mathrm{ml}\end{array}$} & $\mathrm{CON}$ & 46.9 & 40.4 & 18.3 & 31.7 \\
\hline & SHORT & 51.7 & 38.1 & 22.1 & 37.0 \\
\hline & SEM & 1.91 & 1.64 & 1.06 & 2.27 \\
\hline & $P$-value & 0.19 & 0.46 & 0.09 & 0.27 \\
\hline
\end{tabular}

Groups: CON - 5-week far-off period and 3-week close-up period, SHORT - 7-week far-off period and 1-week close-up period; IGF-I - insulin like growth factor I, NEFA - non-esterified fatty acids, BHBA - $\beta$-hydroxybutyric acid, AST - aspartate aminotransferase, T3 - triiodothyronine, T4 - thyroxine; SEM - standard error of mean

day 3 before calving $(P=0.03)$ and tended to have higher T4 levels 5 days after parturition $(P=0.09)$. The activity of AST tended to be lower at day 5 of lactation in the SHORT group $(P=0.06)$, while it tended to be higher at day 28 of lactation in the CON group $(P=0.07)$. Shortening of the closeup period had no effect on blood IGF-I or NEFA concentrations $(P>0.05)$.

There were no differences between the two treatment groups (CON and SHORT) in milk yield (Figure 1) or milk composition during the first 56 days of lactation $(P>0.05$; Figure 2$)$. However, 


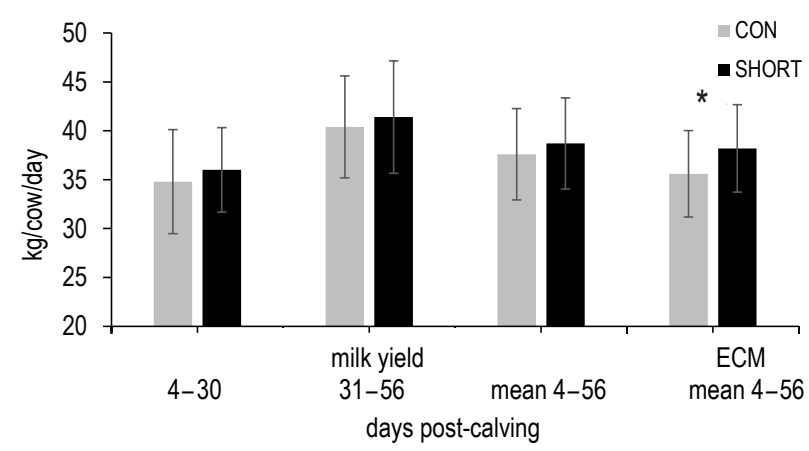

Figure 1. The effect of shortening the close-up period on milk yield and mean energy corrected milk yield (ECM)

Groups: CON - 5-week far-off period and 3-week close-up period, SHORT - 7-week far-off period and 1-week close-up period; mean \pm standard deviation; ${ }^{*}$ - indicates the tendency at $P \leq 0.1$

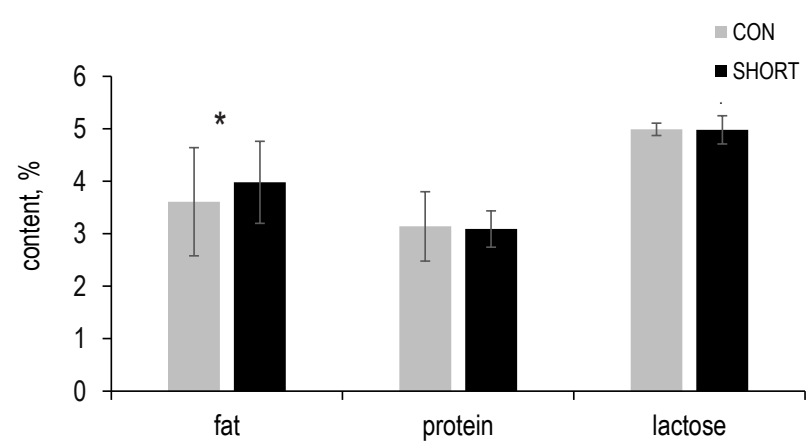

Figure 2. The effect of shortening close-up period on mean (days 4-56) fat, protein and lactose contents in milk

Groups: CON - 5-week far-off period and 3-week close-up period, SHORT - 7-week far-off period and 1-week close-up period; mean \pm standard deviation; ${ }^{*}$ - indicates the tendency at $P \leq 0.1$

cows from the SHORT group tended to produce higher mean energy corrected milk at $38.2 \mathrm{vs} 35.6 \mathrm{~kg}$ $(P=0.09)$ with higher fat contents of 3.98 vs $3.69 \%$ $(P=0.11)$. During the first 56 days of lactation the mean milk urea concentrations and somatic cell counts were similar between the treatment groups $(P>0.05$, data not shown).

Shortening the close-up period had no effect on fertility indices, days to first ovulation, first service conception rate, services per conception and day open $(P>0.05$; Table 6$)$.

Table 6. The effect of shortening the close-up period on reproductive performance

\begin{tabular}{lllll}
\hline Group & $\begin{array}{l}\text { Days to first } \\
\text { ovulation }\end{array}$ & $\begin{array}{l}\text { First-service con- } \\
\text { ception rate }\end{array}$ & $\begin{array}{l}\text { Services per } \\
\text { conception }\end{array}$ & $\begin{array}{l}\text { Days } \\
\text { open }\end{array}$ \\
\hline CON & 23 & 0.45 & 2.36 & 124 \\
SHORT & 19 & 0.33 & 2.62 & 144 \\
SEM & 2.27 & 0.10 & 0.41 & 15.5 \\
$P$-value & 0.48 & 0.57 & 0.45 & 0.49 \\
\hline
\end{tabular}

Groups: CON - 5-week far-off period and 3-week close-up period, SHORT - 7-week far-off period and 1-week close-up period; SEM - standard error of mean
The total incidence of health problems (dystocia, displaced abomasum, hypocalcemia, mastitis, metritis, ketosis, foot and leg problems) after parturition were similar between thein both groups and amounted 8 and 6 cases, respectively for the CON and SHORT group (data not shown). No predisposition to specific health problems was observed in the groups.

\section{Discussion}

We hypothesized that simplification of dairy cow transition period management, shortening the close-up period to one week and implementation of a low energy far-off diet one week before parturition, followed by a high energy fresh transition diet with no close-up diet could have a positive effect on the metabolism of lactating cows as well as improve their fertility and milk production.

The cows in both groups were dried 56 days before the expected calving date to a similar BCS of 3.65. Shortening the close-up period had no effect on BCS or condition changes during the dry period; however, cows assigned to the SHORT group tended to experience the lowest BCS losses during the first 56 days of lactation. Similar results, greater BCS and body weight losses were observed in cows fed high density close-up diets (Zhang et al., 2015). The basic role of the adipose tissue is connected with fatty acids storage supporting productivity. Extreme condition losses after calving could reflect excessive mobilization of body fat reserves from the adipose tissue and indicate clinical signs of ketosis. Thus, a decrease in body condition after calving could be a marker of the energy status of a cow. In the present study BCS losses during the first 56 days of lactation in both groups were moderate (CON -0.29 and SHORT - 0.13) and reasonably expected as physiological changes (Šamanc et al., 2010). Body condition losses were consistent with the NEFA concentrations, which were comparable in both groups, showing no statistical differences. da Fonseca et al. (2004) claimed that when energy balance is stabilized during lactation the NEFA value may be up to $0.25 \mathrm{mmol} / \mathrm{l}$. In spite of lower body condition losses, the NEFA level exceeded $0.26 \mathrm{mmol} / 1$ in both groups during early lactation, which may be used for subacute ketosis diagnosis (Asl et al., 2011). Ketotic cows are immuno-suppressed during the postpartum period. Elevated blood NEFA concentrations mimic intense lipomobilization and thus could be diagnostic tools for impaired periparturient immunity markers, suggesting an increased risk of infection (Ospina 
et al., 2010a). LeBlanc et al. (2005) stated that the NEFA concentration during the first week after parturition exceeding $1.0 \mathrm{mEq} / 1$ is a critical threshold for displaced abomasum; however, Ospina et al. (2010a) set $\geq 0.72 \mathrm{mEq} / 1$ as the cut-off point for NEFA levels. In the present study, blood NEFA concentrations in both groups were below this threshold. In addition, no case of displaced abomasum was reported. Moreover, González et al. (2011) stated that BHBA concentration is a better maker of energy imbalance postpartum than NEFA, while ketosis in cows may be diagnosed at a blood BHBA concentration exceeding $1.2 \mathrm{mmol} / 1$ (Sevinç et al., 1998). Additionally, when fat infiltrates the liver the activity of enzymes (AST, $\gamma$-glutamyltransferase and glutamate dehydrogenase) is higher, which indicates liver injury (Bobe et al., 2004). In the present study the activity of AST was moderate below the cut-off point of $100 \mathrm{U} / 1$, which is used to indicate hepatic lesions (González et al., 2011). Lipid metabolism is controlled by glucose, insulin and growth hormone as well as epinephrine and norepinephrine. Lower blood insulin concentration was connected with increased lipolysis and elevated blood NEFA concentration (Chapinal et al., 2012). Additionally, Vernon (2005) argued that insulin is involved in the lipid metabolism of cows in the perinatal period, reducing blood NEFA and BHBA concentrations. The observed metabolite changes in our study partially confirm this hypothesis. Shortening the close-up period had a positive effect on higher insulin concentrations and the lowest BHBA levels at day 28 of lactation.

Complete NEFA oxidation generates metabolites (acetyl-CoA), which may be used to generate energy via the Krebs cycle or the tricarboxylic acid cycle. The lowest BHBA concentration with a similar NEFA level observed in the SHORT group seems to confirm better NEFA oxidation for energy and the lowest conversion to ketones in the liver, which is a positive effect. Glucose is widely acknowledged as a factor determining complete NEFA oxidation. In the present study glucose concentrations at day 28 of lactation in both groups were comparable with no significant differences and were observed. A similar observation, showing no effect of the prepartum energy density diet on blood glucose concentration during early lactation was reported by Zhang et al. (2015). This result confirmed that blood glucose concentration is not an effective marker of energy balance and thus it cannot be used as a marker of the glucose pool. Our observation was similar to that obtained by Chung et al. (2009) who argued that there are only slight changes in glucose concentration, which may result from the high effectiveness of the system regulating the blood level of this marker. A similar theory was postulated by LeBlanc (2010) who argued that the application of glucose as a marker of metabolic status is questionable in view of the homeostatic glucose regulation. Thus, it likely seems that insulin is the key hormone in NEFA oxidation. Insulin also facilitates glucose passage through cell membranes, which affects endocrine regulation of blood glucose concentrations. It is known that both thyroid hormones (T3 and T4) are involved in the adaptation of energy metabolism in dairy cows and as such may reflect the energy balance of dairy cows (MohebbiFani et al., 2009). Blood concentrations of $\mathrm{T} 3$ and $\mathrm{T} 4$ decrease after calving and then begin to rise. Thus, a higher T3 blood concentration 3 days before parturition and a tendency to higher blood T4 level at day 5 of lactation partly confirmed the better energy balance in cows assigned to the SHORT group. Many authors have shown the effect of thyroid hormones on ovarian activity in cattle (Kafi et al., 2012). Additionally, Huszenicza et al. (2002) indicated that low T3 and T4 concentrations may have a negative effect on postpartum reproductive functions. This concurs with Reist et al. (2003) who showed that high plasma levels of both thyroid hormones were associated with early ovarian activity and onset of ovulation in dairy cows. Kafi et al. (2012) hypothesized that a higher postpartum serum T4 concentration could result in the disturbance of gonadotrophin releasing hormone $(\mathrm{GnRH})$ and luteinizing hormone (LH) secretions. Mohebbi-Fani et al. (2009) found a positive correlation between serum T4 and BHBA concentrations in fresh dairy cows. In turn, Kafi et al. (2012) reported higher serum BHBA levels and BCS loss as a reflection of higher lipolysis in anoestrus cows. Gerloff et al. (1986) showed that thyroid hormone serum concentrations were negatively correlated with liver triglycerides and blood NEFA concentrations. In our study the slight positive metabolic effect observed in cows assigned to the SHORT group did not result in any improvement of fertility parameters. Chapinal et al. (2012) found no relationship between NEFA and BHBA blood concentrations around calving and first insemination efficiency. Generally, an association between fertility and NEFA and BHBA blood concentration is known; however, Chapinal et al. (2012) indicated that the underlying mechanism of negative energy balance during the transition period influencing reproductive performance some weeks later is unclear. Probably, poor fertility is connected with the toxic effect of NEFA and BHBA on oocyte maturation, as was shown by Leroy et al. (2006). 
Despite the slightly positive metabolic changes observed in cows with shortened the close-up period to 1 week, no statistical milk performance differences were observed. Cows assigned to both groups had NEFA concentrations below $0.5 \mathrm{mEq} / 1$ (day 28), which was stated by Chapinal et al. (2012) to be a threshold for predicting a reduction in milk yield. Similarly, Mann et al. (2015) investigated different energy requirements during the dry period and observed no milk performance differences between cows, in spite of significantly relevant metabolic changes. In turn, Zhang et al. (2015) found no statistical effects of prepartum energy density diet on milk yield or composition, despite the fact that cows fed low (1.25 Mcal NE $/ \mathrm{kg}$ ) or medium (1.41 $\mathrm{Mcal} \mathrm{NE}_{\mathrm{L}} /$ $\mathrm{kg}$ ) density diets during the close-up period produced approx. $2 \mathrm{~kg} / \mathrm{d}$ more milk in comparison to cows from the high density $\left(1.55 \mathrm{Mcal} \mathrm{NE}_{\mathrm{L}} / \mathrm{kg}\right)$ pre-calving group.

Additionally, cows fed a high-energy diet $(150 \%$ of requirement) during the transition period had higher postpartum NEFA and BHBA blood concentrations (Mann et al., 2015). These results partially confirm our findings in the present study, where cows with the close-up period shortened to 1 week were simultaneously fed higher energy diets and as a result had lower BHBA concentrations 28 days after calving. Shortening of the close-up period to 1 week had no effect on milk composition; however, a tendency to higher fat content in milk was observed in cows from the SHORT group. This fact could explain a tendency to higher ECM yields recorded in the SHORT group. The effect of prepartum feeding on milk fat contents during lactation is not clear (Zhang et al., 2015). Janovick and Drackley (2010) reported a higher fat content milk of overfed cows, which was associated with greater BCS losses. Mann et al. (2015) interpreted higher milk fat contents by increasing mobilization of fat depots in the first weeks of lactation. Then, the dietary supply of fatty acids precursors, such as acetate and glucose, decreased causing lower synthesis of short chain fatty acids by the mammary tissues and an increased mobilization of fatty acids from adipocytes. It seems that cows assigned to the SHORT group experienced a higher negative energy balance than the CON group; however, this was not confirmed by BCS changes or blood parameters. Moreover, it is generally known that during a negative energy balance an increased fat concentration and decreased protein content in milk it is observed. Thus according to Heuer et al. (1999) fat and protein ratios might be used as potential indicators of lack of energy supply through feed. Duffield et al. (1997) reported that a fat:protein ratio greater than 1.5 is indicator of energy deficiency. In the present study the mean milk fat:protein ratio in the SHORT group was 1.29 , which is below this threshold.

\section{Conclusions}

Simplification of the transition period management in dairy cows and shortening the close-up period did not improve fertility or milk performance, although it resulted in a positive tendency to higher energy corrected milk yields with no negative influence on the metabolic status or reproductive performance in dairy cows. Based on the obtained results we can suggest the use of shortened pre-calving feeding strategy ( 7 weeks of far-off diet and then a fresh transition diet from 1 week before calving to 21 days after parturition), which allows to omit the close-up diet and is easy to implement in practice.

In a similar, earlier study (Nowak et al., 2012) we implied that cow energy nutrition during the dry period with the close-up period reduced to 1 week exerts no negative effect on colostrum quality or the immune status of calves, however, further studies are necessary to confirm this hypothesis concerning the described feeding strategy.

\section{Acknowledgments}

The study was supported by the Polish State Committee for Scientific Research, Grant No. N311 266734 entitled: 'Effect of nutrition during dry period on metabolic and hormonal status, fertility and milk production parameters in dairy cows'.

The authors would like to thank Janusz Kędziora and the Wilkowice farm (Poland) staff for care, management and feeding of cows.

\section{References}

Adamski M., Kupczyński R., Chladek G., Falta D., 2011. Influence of propylene glycol and glycerin in Simmental cows in periparturient period on milk yield and metabolic changes. Arch. Tierzucht. 54, 238-248, https://doi.org/10.5194/aab-54-2382011

AOAC International, 2005. Official Methods of Analysis of the AOAC. $18^{\text {th }}$ Edition, Gaithersburg, MD (USA)

Asl A.N., Nazifi S., Ghasrodashti A.R., Olyaee A., 2011. Prevalence of subclinical ketosis in dairy cattle in the Southwestern Iran and detection of cutoff point for NEFA and glucose concentrations for diagnosis of subclinical ketosis. Prev. Vet. Med. 100, 38-43, https://doi.org/10.1016/j.prevetmed.2011.02.013 
Bobe G., Young J.W., Beitz D.C., 2004. Invited review: Pathology, etiology, prevention, and treatment of fatty liver in dairy cows. J. Dairy Sci. 87, 3105-3124, https://doi.org/10.3168/jds.S00220302(04)73446-3

Chapinal N., Carson M., Duffield T.F., Capel M., Godden S., Overton M., Santos J.E.P., LeBlanc S.J., 2011. The association of serum metabolites with clinical disease during the transition period. J. Dairy Sci. 94, 4897-4903, https://doi.org/10.3168/jds.20104075

Chapinal N., Carson M.E., LeBlanc S.J., Leslie K.E., Godden S., Capel M., Santos J.E.P., Overton M.W., Duffield T.F., 2012. The association of serum metabolites in the transition period with milk production and early-lactation reproductive performance. J. Dairy Sci. 95, 1301-1309, https://doi.org/10.3168/jds.20114724

Chung Y.-H., Brown N.E., Martinez C.M., Cassidy T.W., Varga G.A., 2009. Effects of rumen-protected choline and dry propylene glycol on feed intake and blood parameters for Holstein dairy cows in early lactation. J. Dairy Sci. 92, 2729-2736, https://doi. org/10.3168/jds.2008-1299

da Fonseca L.F.L., Rodrigues P.H.M., dos Santos M.V., Lima A.P., de Sousa Lucci C., 2004. Supplementation of dairy cows with propylene glycol during the periparturient period: effects on body condition score, milk yield, first estrus post-partum, $\beta$-hydroxybutyrate, non-esterified fatty acids and glucose concentrations. Ciênc. Rural 34, 897-903, https://doi.org/10.1590/ S0103-84782004000300037

Dann H.M., Litherland N.B., Underwood J.P., Bionaz M., D'Angelo A., McFadden J.W., Drackley J.K., 2006. Diets during far-off and close-up dry periods affect periparturient metabolism and lactation in multiparous cows. J. Dairy Sci. 89, 3563-3577, https:// doi.org/10.3168/jds.S0022-0302(06)72396-7

Duffield T.F., Kelton D.F., Leslie K.E., Lissemore K.D., Lumsden J.H., 1997. Use of test day milk fat and milk protein to detect subclinical ketosis in dairy cattle in Ontario. Can. Vet. J. 38, 713-718

Duncombe W.G., 1964. The colorimetric micro-determination of nonesterified fatty acids in plasma. Clin. Chim. Acta 9, 122-125, https://doi.org/10.1016/0009-8981(64)90004-X

Edmonson A.J., Lean I.J., Weaver L.D., Farver T., Webster G., 1989. a body condition scoring chart for Holstein dairy cows. J. Dairy Sci. 72, 68-78, https://doi.org/10.3168/jds.S00220302(89)79081-0

Gerloff B.J., Herdt T.H., Wells W.W., Nachreiner R.F., Emery R.S., 1986. Inositol and hepatic lipidosis. II. Effect of inositol supplementation and time from parturition on serum insulin, thyroxine and triiodothyronine and their relationship to serum and liver lipids in dairy cows. J. Anim. Sci. 62, 1693-1702, https://doi. org/10.2527/jas1986.6261693x

González F.D., Muiño R., Pereira V., Campos R., Benedito J.L., 2011. Relationship among blood indicators of lipomobilization and hepatic function during early lactation in high-yielding dairy cows. J. Vet. Sci. 12, 251-255, https://doi.org/10.4142/ jvs.2011.12.3.251

Heuer C., Schukken Y.H., Dobbelaar P., 1999. Postpartum body condition score and results from the first test day milk as predictors of disease, fertility, yield, and culling in commercial dairy herds. J. Dairy Sci. 82, 295-304, https://doi.org/10.3168/jds.S00220302(99)75236-7

Huszenicza G., Kulcsar M., Rudas P., 2002. Clinical endocrinology of thyroid gland function in ruminants. Vet. Med.-Czech 47, 199-210

Janovick N.A., Drackley J.K., 2010. Prepartum dietary management of energy intake affects postpartum intake and lactation performance by primiparous and multiparous Holstein cows. J. Dairy Sci. 93, 3086-3102, https://doi.org/10.3168/jds.2009-2656
Kafi M., Tamadon A., Saeb M., Mirzaei A., Ansari-Lari M., 2012. Relationships between thyroid hormones and serum energy metabolites with different patterns of postpartum luteal activity in high-producing dairy cows. Animal 6, 1253-1260, https:// doi.org/10.1017/S1751731112000043

LeBlanc S., 2010. Monitoring metabolic health of dairy cattle in the transition period. J. Reprod. Dev. 56, Suppl., S29-S35, https://doi.org/10.1262/jrd.1056S29

LeBlanc S.J., Leslie K.E., Duffield T.F., 2005. Metabolic predictors of displaced abomasum in dairy cattle. J. Dairy Sci. 88 , 159-170, https://doi.org/10.3168/jds.S0022-0302(05)72674-6

Leroy J.L.M.R., Vanholder T., Opsomer G., Van Soom A., de Kruif A., 2006. The in vitro development of bovine oocytes after maturation in glucose and $\beta$-hydroxybutyrate concentrations associated with negative energy balance in dairy cows. Reprod. Domest. Anim. 41, 119-123, https://doi.org/10.1111/ j.1439-0531.2006.00650.x

Mann S., Leal Yepes F.A., Overton T.R., Wakshlag J.J., Lock A.L., Ryan C.M., Nydam D.V., 2015. Dry period plane of energy: Effects on feed intake, energy balance, milk production, and composition in transition dairy cows. J. Dairy Sci. 98, 3366-3382, https://doi.org/10.3168/jds.2014-9024

Mohebbi-Fani M., Nazifi S., Rowghani E., Bahrami S., Jamshidi O., 2009. Thyroid hormones and their correlations with serum glucose, beta hydroxybutyrate, nonesterified fatty acids, cholesterol, and lipoproteins of high-yielding dairy cows at different stages of lactation cycle. Comp. Clin. Pathol. 18, 211-216, https://doi.org/10.1007/s00580-008-0782-7

Nowak W., Mikuła R., Pruszyńska-Oszmałek E., Maćkowiak P., Stefańska B., Kasprowicz-Potocka M., Frankiewicz A., Drzazga K., 2013. Dietary energy density in the dry period on the metabolic status of lactating cows. Pol. J. Vet. Sci. 16, 715-722, https://doi.org/10.2478/pjvs-2013-0101

Nowak W., Mikuła R., Zachwieja A., Paczyńska K., Pecka E., Drzazga K., Ślósarz P., 2012. The impact of cow nutrition in the dry period on colostrum quality and immune status of calves. Pol. J. Vet. Sci. 15, 77-82, https://doi.org/10.2478/ v10181-011-0117-5

Ospina P.A, Nydam D.V., Stokol T., Overton T.R., 2010a. Evaluation of nonesterified fatty acids and $\beta$-hydroxybutyrate in transition dairy cattle in the northeastern United States: Critical thresholds for prediction of clinical diseases. J. Dairy Sci. 93, 546-554, https://doi.org/10.3168/jds.2009-2277

Ospina P.A., Nydam D.V., Stokol T., Overton T.R., $2010 \mathrm{~b}$. Associations of elevated nonesterified fatty acids and $\beta$-hydroxybutyrate concentrations with early lactation reproductive performance and milk production in transition dairy cattle in the northeastern United States. J. Dairy Sci. 93, 1596-1603, https://doi.org/10.3168/jds.2009-2852

Piantoni P., Allen M.S., 2015. Evaluation of propylene glycol and glycerol infusions as treatments for ketosis in dairy cows. J. Dairy Sci. 98, 5429-5439, https://doi.org/10.3168/ jds.2015-9476

PN ISO 6491:2000. Determination of phosphorus content Spectrometric method

PN-EN ISO 16472:2007. Determination of amylase-treated neutral detergent fibre content (aNDF)

PN-EN ISO 13906:2009. Animal feeding stuffs - Determination of acid detergent fibre (ADF) and acid detergent lignin (ADL) contents

Reist M., Erdin D.K., von Euw D. et al., 2003. Postpartum reproductive function: association with energy, metabolic and endocrine status in high yielding dairy cows. Theriogenology $59,1707-$ 1723, https://doi.org/10.1016/S0093-691X(02)01238-4 
Roberts T., Chapinal N., LeBlanc S.J., Kelton D.F., Dubuc J., Duffield T.F., 2012. Metabolic parameters in transition cows as indicators for early-lactation culling risk. J. Dairy Sci. 95, 3057-3063,https://doi.org/10.3168/jds.2011-4937

Roche J.R., Meier S., Heiser A., Mitchell M.D., Walker C.G., Crookenden M.A., Vailati Riboni M., Loor J.J., Kay J.K., 2015. Effects of precalving body condition score and prepartum feeding level on production, reproduction, and health parameters in pasture-based transition dairy cows. J. Dairy Sci. 98, 7164-7182, https://doi.org/10.3168/jds.20149269

Šamanc H., Kirovski D., Jovanović M., Vujanac I., BojkovićKovačević S., Jakić-Dimić D., Prodanović R., Stajković S., 2010. New insights into body condition score and its association with fatty liver in Holstein dairy cows. Acta Vet. Brno 60, 525-540, https://doi.org/10.2298/AVB1006525S

Sevınç M., Başoğlu A., Öztok I., Sandikçi M., Bırdane F., 1998. The clinical-chemical parameters, serum lipoproteins and fatty infiltration of the liver in ketotic cows. Turk. J. Vet. Anim. Sci. 22, 443-447

Sordillo L.M., Mavangira V., 2014. The nexus between nutrient metabolism, oxidative stress and inflammation in transition cows. Animal Prod. Sci. 54, 1204-1214, https://doi.org/10.1071/ AN14503
Sordillo L.M., Raphael W., 2013. Significance of metabolic stress, lipid mobilization, and inflammation on transition cow disorders. Vet. Clin. N. Am.-Food Anim. Pract. 29, 267-278, https://doi. org/10.1016/j.cvfa.2013.03.002

Suriyasathaporn W., Heuer C., Noordhuizen-Stassen E.N., Schukken Y.H., 2000. Hyperketonemia and the impairment of udder defense: a review. Vet. Res. 31, 397-412, https://doi. org/10.1051/vetres:2000128

Vernon R.G., 2005. Lipid metabolism during lactation: a review of adipose tissue-liver interactions and the development of fatty liver. J. Dairy Res. 72, 460-469, https://doi.org/10.1017/ S0022029905001299

Walsh R.B., Walton J.S., Kelton D.F., LeBlanc S.J., Leslie K.E., Duffield T.F., 2007. The effect of subclinical ketosis in early lactation on reproductive performance of postpartum dairy cows. J. Dairy Sci. 90, 2788-2796, https://doi.org/10.3168/ jds.2006-560

Zhang Q., Su H., Wang F., Cao Z., Li S., 2015. Effects of energy density in close-up diets and postpartum supplementation of extruded full-fat soybean on lactation performance and metabolic and hormonal status of dairy cows. J. Dairy Sci. 98, 7115-7130, https://doi.org/10.3168/jds.2014-9112 